\title{
PENGARUH PEMBERIAN PUPUK KANDANG AYAM TERHADAP PERTUMBUHAN TANAMAN SORGUM SEBAGAI PAKAN
}

\author{
Maria J. Silalahi, A. Rumambi, Malcky. M. Telleng, W.B. Kaunang
}

Fakultas Peternakan Universitas Sam Ratulangi Manado

\begin{abstract}
ABSTRAK
Sorgum (Sorghum bicolor (L.) Moench) merupakan tanaman serealia yang potensial untuk dibudidayakan dan dikembangkan di Indonesia khususnya pada daerah-daerah marginal dan kering sebagai pakan ruminansia. Tujuan penelitian adalah untuk mengetahui dan memperoleh data pengaruh pemberian pupuk kandang ayam terhadap pertumbuhan sorgum. Rancangan yang digunakan adalah Rancangan Acak Lengkap (RAL) yang terdiri dari 4 perlakuan dan 5 ulangan sehingga diperoleh 20 satuan percobaan. Untuk melihat sejauh mana satu perlakuan berbeda nyata dengan perlakuan lainnya, analisis dilanjutkan dengan uji beda nyata jujur. Perbedaan secara statistik dinyatkan pada $\mathrm{P}<0,05$. Perlakuan terdiri dari $\mathrm{P} 0=$ tanpa pemupukan, $\mathrm{P} 1=$ Pemupukan 3,5 ton/ha, P2= Pemupukan 4,5 ton/ha dan P3= Pemupukan 6.5 ton/ha. Variabel yang diukur adalah tinggi tanaman, jumlah daun dan panjang daun. Hasil analisis sidik ragam menunjukkan bahwa perlakuan memberikan pengaruh nyata $(\mathrm{P}<0,05)$ terhadap tinggi tanaman, jumlah daun, dan panjang daun. Uji lanjut BNJ menunjukkan bahwa perlakuan menggunakan pupuk kandang ayam dosis 6.5 ton/ha berbeda sangat nyata $(\mathrm{P}<0.01)$ lebih tinggi dibandingkan dengan tanpa pemupukan ( $\mathrm{P} 0 /$ kontrol), dosis pemupukan 3,5 ton/ha (P1) dan dosis pemupukan 4,5 ton/ha (P2) terhadap tinggi tanaman, jumlah daun, dan panjang daun.
\end{abstract}

*Korespondensi (Corresponding author)

Email: agnitjerumamb@ymail.com
Berdasarkan hasil penelitian dapat disimpulkan bahwa pemberian pupuk kandang ayam sampai dengan dosis 6,5 ton/ha memberikan pengaruh terbaik terhadap tinggi tanaman, jumlah daun dan panjang daun tanaman sorgum.

Kata kunci: Pupuk Kandang Ayam, Pertumbuhan,Sorgum, Pakan

\section{ABSTRACT}

\section{EFFECT OF APPLICATION OF CHICKEN MANURE FERTILIZER ON THE GROWTH OF SUPER-1 SORGHUM VARIETY GROWTH.} Sorghum (Sorghum bicolor (L.) Moench) is a potential cereal crop to be cultivated and developed as a ruminant's fodders in Indonesia, specifically in marginal and dryland areas. The purpose of the present study was to determine the effect of chicken manure as a fertilizer on the growth parameters of super-1 sorghum. This study was conducted using a completely randomized design (CRD) which consists of 4 treatments and 5 replicates in each treatment, with a total of 20 experimental units, was used as experimental design. After a significant $F$ test, Tukey's test (where necessary) was used to inspect treatment differences among group means. Statistical significance was accepted at $\mathrm{P}<0.05$. Treatments were formulated as follow: P0 $=$ no fertilizer (as a control), $\mathrm{P} 1=$ chicken manure fertilizer of 3.5 tonnes/ha, $\mathrm{P} 2=$ chicken manure fertilizer of 4.5 tonnes/ha, and $\mathrm{P} 3=$ chicken manure fertilizer of 6.5 tonnes/ha. Variables measured were: plant 
height, leaves count, and leaves length. Research results showed that treatments gave a significant effect $(\mathrm{P}<0,05)$ on plant height, leaves count, and leaves length. Chicken manure fertilizer of 6.5 ton/ha (P3) had a higher plant height, leaves count, and leaves length values compared with P0 (without fertilizer), P1 (chicken manure fertilizer of 3.5 tonnes/ha), and P2 (chicken manure fertilizer of 4.5 tonnes/ha). It can be concluded that the application of chicken manure fertilizer up to 6.5 tonnes/ha gives the best effect on plant height, leaves count, and leaves length of sorghum crops as a fodder .

Key words: Chicken manure fertilizer, Growth, Sorghum, Fodders

\section{PENDAHULUAN}

Sorgum merupakan salah satu jenis tanaman serealia yang mempunyai potensi besar untuk dikembangkan di Indonesia karena mempunyai daya adaptasi yang luas, toleran terhadap kekeringan dan genangan air, dapat berproduksi pada lahan marginal, serta relatif tahan terhadap gangguan hama atau penyakit. Tanaman sorgum juga berfungsisebagai bahan baku industri yang ragam kegunaanya besar dan merupakan komoditas ekspor dunia.

Sorgum dapat digunakan sebagai sumber pakan baik daun maupun butirannya (biji). Pemberian daun sorgum pada ternak sapi dapat diberikan secara langsung dalam bentuk segar maupun dalam bentuk silase.
Potensi daun sorgum manis sekitar 14-16\% dari bobot segar batang atau sekitar 3 ton/ha daun segar dari total produksi 20 ton/ha, sedangkan untuk nutrisi daun sorgum setara dengan rumput gajah dan pucuk tebu terutama dari segi protein yang masing-masing adalah : 7,8\%, 6,0\% dan 5,0\% (Rumambi, 2013).

Penggunaan biji sorgum dalam ransum pakan ternak bersifat suplementer (substitusi) terhadap jagung karena kandungan nutrisinya hampir sama dengan jagung. Kandungan nutrisi biji sorgum berdasarkan $100 \%$ bahan kering (BK) berupa protein $10,26 \%$; serat kasar $2,72 \%$; lemak 2,70\%; Ca 0.90\%; dan P 0,38\% (Rumambi, 2013), sedangkan produksi BK dan BO sorgum berturut-turut sebagai berikut 58,61\% dan 58,65\% (Koten et al., 2012). Biji sorgum juga dapat dimanfaatkan untuk pakan ayam dan itik, namun pemanfaatan sorgum untuk pakan ternak masih terdapat perbedaan pendapat terkait dengan kandungan tanin sekitar $0,4 \%-3,6 \%$ yang dalam jumlah tertentu dapat menghambat pertumbuhan ternak.

Melihat manfaat sorgum sebagai pakan sehingga perlu peningkatan produktivitas dengan jalan penambahan unsur hara dengan pemanfaatan kotoran kandang ayam sebagai pupuk yang baik. Pemupukan dapat menyediakan unsur hara yang diperlukan oleh tanaman. Dengan pemberian dosis yang tepat diharapkan 
mampu meningkatkan produktivitas tanaman sorgum.

Pemupukan merupakan upaya yang dilakukan untuk mengatasi kekurangan hara, terutama nitrogen $(\mathrm{N})$, fosfor $(\mathrm{P})$, dan kalium (K) yang merupakan unsur-unsur hara makro yang berperan penting dalam pertumbuhan dan produksi tanaman. Ketersediaan N, P, dan K di dalam tanah adalah faktor yang paling membatasi untuk mendapatkan pertumbuhan dan hasil maksimum dari tanaman yang dibudidayakan.

Dengan pertumbuhan akar yang lebih baikakan meningkatkan penyerapan unsur harayang mengakibatkan tinggi tanaman danjumlah daun meningkat. Hal ini sejalan dengan pendapat Subroto (2009), bahwa pemberian pupuk kandang ayam dapat memperbaiki struktur tanah serta dapat memperkuat akar tanaman. Menurut Raihan (2000) menyatakan bahwa penggunaan bahan organik pupuk kandang ayam sebagai pemasok hara tanah dan meningkatkan retensi air, apabila kandungan air tanah meningkat, proses perombakan bahan organik akan banyak menghasilkan asam-asam organik, anion dari asam organik dapat mendesak fosfat yang terikat oleh $\mathrm{Fe}$ da $\mathrm{Al}$ sehingga fosfat dapat terlepas dan tersedia bagi tanaman. Penambahan kotoran ayam berpengaruh positif pada tanah masam berkadar bahan organik rendah karena pupuk organic mampu meningkatkan kadar $\mathrm{P}, \mathrm{K}, \mathrm{Ca}$ dan Mg tersedia.

Menurut Ismaeil et al. (2012) berpendapat bahwa pemberian pupuk kandang ayam pada dosis 5 ton/ha dapat meningkatkan pertumbuhan tanaman sorgum dibandingkan dengan pemberian dosis pupuk kandang ayam 2,5 ton/ha.

Berdasarkan latar belakang diatas maka perlu dilakukan penelitian untuk mengetahui dan memperoleh data pengaruh pemberian pupuk kandang ayam terhadap pertumbuhan tanaman sorgum sebagai pakan.

\section{MATERI DAN METODE PENELITIAN}

Penelitian ini telah dilaksanakan di Desa Mapanget Kecamatan Talawaan Kabupaten Minut, tanggal 15 September sampai dengan 17 Desember 2017.Rancangan yang digunakan adalah Rancangan Acak Lengkap (RAL) menurut Steel dan Torrie (1995) terdiri dari 4 perlakuan dan 5 ulangan sehingga diperoleh 20 satuan percobaan. Petak yang digunakan berukuran 2 x $3 \mathrm{~m}$, jumlah tanaman perpetak adalah 18 tanaman sehingga keseluruhan petak berjumlah 360 tanaman dengan jarak tanam $50 \mathrm{~cm}$ x 50 $\mathrm{cm}$. 
Perlakuan yang diberikan adalah :

P0 = Tanpa Pemupukan

P1 = Pupuk kandang ayam 2,1 kg/petak setara dengan 3,5 ton/ha

P2 = Pupuk kandang ayam 2,7 kg/petak setara dengan 4,5 ton/ha

P3 = Pupuk kandang ayam 3,9 kg/petak setara dengan 6,5 ton/ha

Bahan dan alat yang digunakan yaitu: benih sorgum varietas Super-1, tanah/lahan, pupuk kandang ayam dan air sedangkan alat yang digunakan yaitu: cangkul, gunting, paku, kertas HVS warna, meteran, bambu, plastik, hekter, sekop, parang dan alat tulis menulis, tali rafia, timbangan dan kamera.

\section{Persiapan Lahan}

Pembersihan lahan dengan cara pembajakkan atau pembongkaran tanah kemudian dilakukan penyisiran agar bersih dari sisa-sisa tanaman dan rumput liar dilanjutkan dengan pembuatan petak sebanyak 20 petak dengan ukuran 2 x $3 \mathrm{~m}$, jarak antar petak adalah $50 \mathrm{~cm} \times 50 \mathrm{~cm}$ dan jarak antar tanaman $50 \mathrm{~cm}$ serta jumlah tanaman perpetak adalah 18 tanaman sehingga keseluruhan petak berjumlah 360 tanaman. Tanah yang telah dibuat petak-petak tadi dibiarkan selama 1 minggu untuk membiarkan kesempatan bagi rumput liar tumbuh kemudian dicangkul kembali sekaligus dengan pemberian pupuk sesuai perlakuan pada tiap-tiap petak.

\section{Penanaman}

Penanaman dilakukan dengan cara tugal, dimana setiap lubang ditanami 2-3 butir, setelah tanaman berumur 1 minggu dilakukan penjarangan dengan meninggalkan satu tanaman per lubang. Setiap petak ditanami 18 tanaman sehingga keseluruhan petak berjumlah 360 tanaman.

\section{Pemeliharaan}

Pemeliharaantanaman meliputi penyiangan dilakukan dengan mencabut gulma hingga ke perakarannya secara hatihati, agar tidak mengganggu perakaran tanaman utama dan pengendalian burung dilakukan dengan menutup malai dengan plastik yang diberi lubang.

\section{Panen}

Tanaman sorgum dipanen pada umur 3 bulan, penentuan saat panen sorgum dapat dilakukan dengan berpedoman pada umur dan dapat dilakukan dengan melihat visual biji (biji telah keras dan matang fisiologis.

\section{Variabel yang diukur}

- Tinggi tanaman (cm), pengukuran dilakukan menggunakan penggaris dengan satuan sentimeter $(\mathrm{cm})$, 
- pengukuran ini dilakukan dari pangkal batang (permukaan tanah) sampai pada bagian tertinggi tanaman

- Jumlah daun (helai) yaitu menghitung daun yang sudah terbuka secara sempurna.

- Pengukuran panjang daun yaitu diukur dari pangkal daun sampai ujung daun (daun ke 5 dari akar)

\section{Pengambilan data}

Pengambilan data dilakukan dengan interval 2 minggu setelah tanamanberumur 2 minggu terhadap tinggi tanaman, jumlah daun dan panjang daun sampai pada 10 minggu (70 hari) setelah tanam.

\section{HASIL DAN PEMBAHASAN}

\section{Pengaruh Perlakuan Pupuk Kandang Ayam Terhadap Tinggi Tanaman Sorgum}

Pengaruh perlakuan terhadap tinggi tanaman dapat dilihat pada Tabel 1. Rataan tinggi tanaman tertinggi terdapat pada 10 MST (P3) yaitu $125 \mathrm{~cm}$ diikuti oleh P2 $(120 \mathrm{~cm}), \quad$ P1 $(113,8 \mathrm{~cm})$ dan yang terendah pada perlakuan P0 $(107,2 \mathrm{~cm})$.

Hasil analisis sidik ragam menunjukkan bahwa perlakuan pemupukan memberikan pengaruh nyata $(\mathrm{P}<0,05)$ terhadap tinggi tanaman.Uji lanjut BNJ memperlihatkan bahwa perlakuan menggunakan pupuk kandang ayam dengan dosis 6,5 ton/ha (P3) berbeda sangat nyata $(\mathrm{P}<0,01)$ lebih tinggi dibandingkan dengan tanpa pemupukan (P0/kontrol), dosis pemupukan 3,5 ton/ha (P1) dan dosis pemupukan 4,5 ton/ha (P2) terhadap tinggi tanaman sorgum.

Tabel 1. Rataan Pengaruh Perlakuan Pupuk Kandang Ayam Terhadap Tinggi Tanaman Sorgum $(\mathrm{cm})$

\begin{tabular}{ccccc}
\hline Ulangan & & \multicolumn{3}{c}{ Perlakuan } \\
& P0 & P1 & P2 & P3 \\
\hline U1 & 104 & 117 & 122 & 127 \\
U2 & 106 & 112 & 121 & 124 \\
U3 & 107 & 114 & 120 & 126 \\
U4 & 109 & 115 & 119 & 125 \\
U5 & 110 & 111 & 118 & 123 \\
\hline Total & 536 & 569 & 600 & 625 \\
\hline Rata-Rata & $107,2 \pm 2,39^{\mathrm{d}}$ & $113,8 \pm 2,39^{\mathrm{c}}$ & $120 \pm 1,58^{\mathrm{b}}$ & $125 \pm 1,58^{\mathrm{a}}$ \\
\hline
\end{tabular}

Keterangan: Superscrip yang berbeda pada baris yang sama menunjukkan perbedaan yang nyata 
Semakin tinggi level pemberian pupuk semakin tinggi pertumbuhan tanaman. Hal ini disebabkan karena pupuk kandang ayam memiliki unsur hara yang diperlukan tanaman seperti N, P, K serta unsur hara mikro berupa $\mathrm{Zn}, \mathrm{Fe}$, Modimana menurut Lingga dan Marsono (2008) pupuk kandang ayam mengandung unsur $\mathrm{N}: 1,3 \%, \mathrm{P}_{2} \mathrm{O}_{5}: 1,3 \%$ dan $\mathrm{K}_{2} \mathrm{O}$ : $0,8 \%$.

Pupuk kandang ayam merupakan sumber yang baik bagi unsur-unsur hara makro dan mikro dan mampu meningkatkan kesuburan tanah serta menjadi substrat bagi mikroorganisme tanah dan meningkatkan aktivitas mikroba sehingga lebih cepat terdekomposisi (Odoemena, 2006).

Unsur hara yang terkandung dalam pupuk kandang ayam terutama unsur hara makro yaitu $\mathrm{N}$, $\mathrm{P}$, dan $\mathrm{K}$ berguna bagi pertumbuhan tanaman, dimana unsur $\mathrm{N}$ dibutuhkan untuk pertumbuhan vegetatif tanaman, unsur $\mathrm{K}$ pertumbuhan batang yang lebih kokoh dan kuat, dan unsur $\mathrm{P}$ digunakan untuk merangsang pembungaan dan pembuahan, pertumbuhan akar dan pembentukan biji (Yuwono, 2007).

Hasil penelitian tentang tinggi tanaman ini lebih rendah dari penelitian Rahayu et al. (2012) yang menggunaan pupuk kotoran ayam menghasilkan tinggi tanaman yaitu 200,5 cm demikian juga dengan penelitian Imban et al. (2017) dan Wantania et al. (2017) yang masingmasing adalah: 168,20 $\mathrm{cm}$ dan 196,2 $\mathrm{cm}$ yang menggunakan bokashi feses sapi. Perbedaan hasil penelitian adalah karena perbedaan varietas yang digunakan serta lingkungan tumbuh dari tanaman itu sendiri (Sanusi, 2000).

Tabel 2. Rataan Pengaruh Perlakuan Pupuk Kandang Ayam Terhadap Jumlah Daun Tanaman Sorgum (helai)

\begin{tabular}{ccccc}
\hline Ulangan & & \multicolumn{2}{c}{ Perlakuan } & P2 \\
& P0 & P1 & P2 & P3 \\
\hline U1 & 10,87 & 10,99 & 11,2 & 11,35 \\
U2 & 10,90 & 11 & 11,23 & 11,40 \\
U3 & 10,86 & 11,08 & 11,30 & 11,41 \\
U4 & 10,88 & 11,15 & 11,28 & 11,36 \\
U5 & 10,90 & 10,99 & 11,25 & 11,39 \\
\hline Total & 54,41 & 55,21 & 56,26 & 56,91 \\
\hline Rata-Rata & $10,882 \pm 0,0179^{\mathrm{d}}$ & $11,042 \pm 0,0712^{\mathrm{c}}$ & $11,252 \pm 0,0396^{\mathrm{b}}$ & $11,382 \pm 0,0258^{\mathrm{a}}$
\end{tabular}

Keterangan: Superskrip yang berbeda pada baris yang sama menunjukkan perbedaan yang nyata 
Pengaruh Perlakuan Pupuk Kandang Ayam Terhadap Jumlah Daun

Pengaruh perlakuan terhadap jumlah daun tanaman dapat dilihat pada Tabel 2. Rataan jumlah daun terbanyak pada 10 MST (P3) yaitu 11,382 helai diikuti oleh P2 (11,252 helai), P1 (11,042 helai) dan yang terendah pada perlakuan P0 $(10,882$ helai. Hasil analisis sidik ragam menunjukan bahwa perlakuan pemupukan memberikan pengaruh nyata $(\mathrm{P}<0,05)$ terhadap jumlah daun tanaman sorgum. Uji lanjut BNJ memperlihatkan bahwa perlakuan menggunakan pupuk kandang ayam dengan dosis 6,5 ton/ha (P3) berbeda sangat nyata $(\mathrm{P}<0,01)$ lebih tinggi dibandingkan dengan tanpa pemupukan (P0/kontrol), dosis pemupukan 3,5 ton/ha (P1) dan dosis pemupukan 4,5 ton/ha (P2) terhadap jumlah daun tanaman sorgum.

Hal ini disebabkan oleh ketersediaan unsur hara yang lebih banyak pada perlakuan menggunakan pupuk kandang ayam dosis 6,5 ton/ha dimana jumlah daun berpengaruh terhadap penyediaan makanan bagi tanaman atau fotosintesis (Ishak et al., 2013). Semakin banyak daun semakin tinggi fotosintesis yang terjadi Wahida et al. (2011), daun berfungsi sebagai organ utama fotosintesis pada tumbuhan, efektif dalam penyerapan cahaya dan cepat dalam pengambilan $\mathrm{CO}_{2}$.

Hasil penelitian ini hampir sama dengan hasil penelitian dari Hariadi et al.
(2015) yang menggunakan kombinasi pupuk kandang dan Tricho-kompos memperoleh jumlah daun yaitu 9,83-11,69 helai dan lebih tinggi dari penelitian Imban et al. (2017) yang menggunakan bokashi feses sapi dan memperoleh jumlah daun 10,82 helai.

Pupuk kandang ayam lebih baik dalam meningkatkan kesuburan tanah karena cepat terdekomposisi dan mengandung unsur hara yang lebih lengkap (makro dan mikro) serta mikroorganisme yang ada di dalamnya mampu menguraikan tanah menjadi lebih baik, sehingga beberapa unsur hara dalam tanah seperti $\mathrm{P}$ mudah tersedia dan diserap tanaman. Unsur hara $\mathrm{P}$ dan $\mathrm{K}$ banyak dibutuhkan untuk pertubuhan batang dan cabang dan berfungsi juga untuk pembentukan karbohidrat sehingga menghasilkan jumlah daun yang banyak (Sucipto, 2010).

\section{Pengaruh Perlakuan Pupuk Kandang AyamTerhadap Panjang Daun}

Pengaruh perlakuan terhadap panjang daun tanaman dapat dilihat pada Tabel 3. Rataan panjang daun tanaman tertinggi terdapat pada 10 MST (P3) yaitu 102.38 cm diikuti oleh P2 (98,19 cm), P1 (89,77 $\mathrm{cm})$ dan yang terendah pada perlakuan P0 $(85,77 \mathrm{~cm})$. 
Tabel 3. Rataan Pengaruh Perlakuan Pupuk Kandang Ayam Terhadap Panjang Daun Tanaman Sorgum $(\mathrm{cm})$

\begin{tabular}{ccccc}
\hline Ulangan & & \multicolumn{3}{c}{ Perlakuan } \\
& $\mathrm{P} 0$ & $\mathrm{P} 1$ & $\mathrm{P} 2$ & $\mathrm{P} 3$ \\
\hline U1 & 87,52 & 87,52 & 99,58 & 99,59 \\
U2 & 83,87 & 89,13 & 97,55 & 100,10 \\
U3 & 87,08 & 90 & 99,21 & 112,11 \\
U4 & 84,21 & 91,10 & 99,51 & 99,99 \\
U5 & 86,19 & 91,11 & 95,10 & 100,13 \\
\hline Total & 428,87 & 448,86 & 490,95 & 511,92 \\
\hline Rata-Rata & $85,78 \pm 1,66^{\text {d }}$ & $89,77 \pm 1.51^{\text {c }}$ & $98,19 \pm 1,92^{\text {b }}$ & $102,38 \pm 5,44^{\text {a }}$ \\
\hline
\end{tabular}

Keterangan: Superscrip yang berbeda pada baris yang sama menunjukkan perbedaan yang nyata

Hasil analisis sidik ragam menunjukan bahwa perlakuan pemupukan memberikan pengaruh nyata $(\mathrm{P}<0,05)$ terhadap panjang daun tanaman sorgum. Uji lanjut BNJ memperlihatkan bahwa perlakuan menggunakan pupuk kandang ayam dengan dosis 6,5 ton/ha $(\mathrm{P} 3)$ berbeda sangat nyata $(\mathrm{P}<0,01) \quad$ lebih tinggi dibandingkan dengan tanpa pemupukan (P0/kontrol), dosis pemupukan 3,5 ton/ha (P1) dan dosis pemupukan 4,5 ton/ha (P2) terhadap panjang daun tanaman sorgum.

Hal ini disebabkan karena semakin tingginya pemberian pupuk kandang ayam, yang diketahui memiliki keunggulan kandungan nitrogen lebih tinggi dibandingkan pupuk kandang sapi dan kompos. Penelitian Ishak et al. (2013) menggunakan pupuk kandang ayam dengan dosis 7,5 ton/ha pada tanaman jagung memperoleh rataan panjang daun $82,33 \mathrm{~cm}$. Penelitian ini yaitu $102,38 \mathrm{~cm}$

lebih tinggi dengan menggunakan dosis 6,5 ton/ha. Hal ini menunjukankeunggulansorgum dalam hal penyerapan unsur hara terutama unsur hara $\mathrm{N}$ dan $\mathrm{P}$ dan $\mathrm{K}$ lebih efektif, sehingga terlihat pada pertumbuhan panjang daun yang lebih baik. Sorgum mempunyai sifat adaptifnya yang cukup tinggi dan dalam hal penyerapan hara sehingga dapatdikembangkan di berbagai kondisi lahan di Indonesia (Sungkono, 2007).

\section{KESIMPULAN}

Berdasarkan hasil penelitian yang telah dilaksanakan dapat disimpulkan bahwa pemberian pupuk kandang ayam sampai dengan dosis 6,5 ton/ha memberikan pengaruh terbaik terhadap tinggi tanaman, jumlah daun dan panjang daun tanaman sorgum sebagai pakan. 


\section{DAFTAR PUSTAKA}

Hariadi, F. Puspita dan S. Yosewa. 2015. Pemberian kombinasi pupuk kandang dengan tricho-kompas terhadap pertumbuhan tanaman sorgum (Sorghum bicolor.l). Jurnal Agroekoteknologi 2(1) : 410.

Imban, S.S., A.Rumambidan S. S. Malalantang. 2017. Pengaruh pemanfaatan bokashi feses sapi terhadap pertumbuhan sorgum varietas kawali. Jurnal Zootek. Vol. 37(1): 80-87.

Ishak,Y,S., M. I. Bahua dan M. Limonu. 2013. Pengaruh pupuk organik kotoran ayam terhadap pertumbuhan tanaman jagung manis (Zea mays L.) di Dulomo Utara Kota Gorontalo. JAAT 2 (1):210-216.

Ismaeil, F.M., A.O.Abusuwar and A.M. Naim. 2012. Influence of chicken manure on growth and yield of forage sorghum (Sorghum bicolor L. Moench). International Journal of Agriculture and Foresty 2(2): 56-60

Koten, B.B., R.Dj. Soetrisnodan B.Suwignyo. 2012. Produksi tanaman sorgum (Shorgum bocolor L. Moench) varietas local rote sebagai hijauan pakan ruminansia pada umur panen dan dosis pupuk urea yang berbeda. Buletin Peternakan 36 (3) : 150-155.

Lingga dan Marsono. 2008. Petunjuk Pengunaan Pupuk. Penebar Swadaya. Jakarta.

Odoemena, C.S.I.2006. Effect of poultry manure on growth, yield and chemical composition of tomato
(Lycopersicon escultentum, Mill) cultivars. IJNAS 1(1):51-55.

Rahayu, Muji., Samanhudi dan Wartoyo. 2012. Uji adaptasi beberapa varietas sorgum manis di lahan kering wilayah Jawa Tengah dan Jawa Timur. J. Caraka Tani. Vol. 27(1) :53-62

Raihan, H.S. 2000. Pemupukan NPK dan ameliorasi lahan kering sulfat masam berdasarkan nilai uji tanah untuk tanaman jagung. J. Ilmu pertanian 9 (1): 20-28

Rumambi, A. 2013. Karakteristik pertumbuhan sorgum dengan pemupukan urea berbeda sebagai sumber nitrogen. Jurnal Agrosistem Vol 10(1):1-12.

Sanusi. 2000. Respon Beberapa Varietas Jagung (Zea mays L.) pada Berbagai Dosis Pupuk Urea. Tesis tidak diterbitkan. Makassar: Program Pascasarjana Unhas.

Steel, R.G.D and J.H. Torrie. 1995. Prinsip dan Prosedur Statistika Suatu Pendekatan Biometrik, Jakarta. Terjemahan PT Gramedia.

Subroto. 2009. Kesuburan dan Pemupukan Tanah Pertanian. Bandung: Pustaka Buana.

Sucipto. 2010. Efisiensi cara pemupukan terhadap pertumbuhan dan hasil beberapa varietas sorgum manis (sorgum bicolor (L). moench). Jurnal Embryo 7(2): 67-74.

Sungkono. 2007. Seleksi tanaman sorgum [Sorghum bicolor (L.) Moench] untuk produktivitas biji dan bioetanol tinggi pada tanah masam melalui pendekatan Participatory Plant Breeding. Disertasi. Sekolah 
Pascasarjana Institut Pertanian Bogor.

Wahida, R.S. Nadira, H.L. Hernusye. 2011. Aplikasi Pupuk Kandang Ayam Pada Tiga Varietas Sorgum (Sorghum Bicolor L. Moench. http://pasca.unhas.ac.id/jurnal/files/ d2d881d09802af860dd274c7b7317 40d.pdf.

Wantania. D. I., A. Rumambi, dan W. B. Kaunang. 2017. Pemanfaatan Bokashi Feses Sapi Terhadap Produktivitas RatunSorgum Varietas Kawali. Jurnal Zootek Vol. 38No. 1: 9 -16.

Yuwono, N.W. 2007. Unsur Hara Dalam Tanah (Makro dan Mikro). 